Int. J. Electrochem. Sci., 12 (2017) 9250 - 9261

\title{
Bulk Heterojunction Tandem Photoelectric Cell Based on p-Si and Phthalocyanine
}

\author{
Muhammad Tariq Saeed Chani ${ }^{1,2, *}$, Kh.S.Karimov $^{3,4}$, Hadi M. Marwani ${ }^{1,2}$, Ekram Y. Danish ${ }^{1}$, Waleed \\ Ahmad $^{5}$, Jamil-un Nabi $^{3}$, M.Hilal $^{3}$, Anders Hagfeldt ${ }^{6}$, Abdullah M. Asiri, ${ }^{1,2}$ \\ ${ }^{1}$ Department of Chemistry, Faculty of Science, King Abdulaziz University, Jeddah 21589, P.O. Box \\ 80203, Saudi Arabia \\ ${ }^{2}$ Center of Excellence for Advanced Materials Research (CEAMR), King Abdulaziz University, \\ Jeddah 21589, P.O. Box 80203, Saudi Arabia \\ ${ }^{3}$ Ghulam Ishaq Khan Institute of Engineering Sciences and Technology, Topi, Khyber Pakhtunkhwa, \\ Pakistan \\ ${ }^{4}$ Center for Innovative Development of Science and New Technologies of Academy of Sciences, \\ Rudaki Ave.33, 734025, Dushanbe, Tajikistan \\ ${ }^{5}$ Department of Electrical and Computer Engineering, King Abdulaziz University Jeddah 21589, P. O. \\ Box 80204, Saudi Arabia \\ ${ }^{6}$ Laboratory of Photomolecular Science. Ecole Polytechnique Fédérale de Lausanne, CH-1015 \\ Lausanne, Switzerland. \\ *E-mail: tariqchani1@gmail.com
}

doi: $10.20964 / 2017.10 .55$

Received: 5 June 2017 / Accepted: 8 August 2017 / Published: 12 September 2017

\begin{abstract}
An organic-inorganic (p-Si and phthalocyanine) hybrid tandem heterojunction Ag/p-Si/AlPc: $\mathrm{H}_{2} \mathrm{Pc} / \mathrm{ITO}$ photoelectric cell was fabricated by pressing technology using preliminary vapor deposited heterojunction films of mixed aluminum-phthalocyanine (AlPc) and metal free phthalocyanine $\left(\mathrm{H}_{2} \mathrm{Pc}\right)$ on $\mathrm{p}-\mathrm{Si}$ substrate and on ITO coated plastic substrate. By keeping organic films face to face both substrates were pressed and fixed together by adhesive at elevated temperature. Total thickness of the AlPc and $\mathrm{H}_{2} \mathrm{Pc}$ films were equal to $300 \mathrm{~nm}$. On the back side of $\mathrm{p}-\mathrm{Si}$ substrate the $\mathrm{Ag}$ film was deposited. The device architecture was the following: Ag/p-Si/AlPc: $\mathrm{H}_{2} \mathrm{Pc} / \mathrm{ITO}$. The morphology of the organic semiconductors film was investigated by AFM. The optical properties of the AlPc: $\mathrm{H}_{2} \mathrm{Pc}$ film were studied by UV-visible spectroscope. Current-Voltage characteristics were measured in dark and also illumination conditions. Under illumination of $296 \mathrm{~W} / \mathrm{m}^{2}$ the values of $V_{o c}, I_{S C}, F F$ and efficiency were equal to $0.5 \mathrm{~V}, 4 \mathrm{~mA}, 0.45$ and $0.61 \%$, respectively. The $I-V$ and $P-V$ characteristics of the solar cell were simulated by using Shockley equation and its Newton Raphson solution, respectively for dark and illumination conditions. The obtained simulated results were in good agreement with the experimental results.
\end{abstract}


Keywords: pressing-technology; thermal evaporation; organic-inorganic; phthalocyanine; photoelectric cell

\section{$\underline{\text { FULL TEXT }}$}

(C) 2017 The Authors. Published by ESG (www.electrochemsci.org). This article is an open access article distributed under the terms and conditions of the Creative Commons Attribution license (http://creativecommons.org/licenses/by/4.0/). 